\title{
Pengaruh Desentralisasi Dan Ketidakpastian Tugas Terhadap Kinerja Manajerial Dengan Sistem Akuntansi Manajemen Sebagai Variabel Intervening
}

\author{
Herman Wijaya \\ Unsera.herman@gmail.com \\ Jurusan Akuntansi \\ Universitas Serang Raya
}

\begin{abstract}
Abstrak
Penelitian ini bertujuan untuk menguji pengaruh variable Desentralisasi dan ketidakpastian tugas terhadap kinerja manajerial melalui sistem akuntansi manajemen (SAM) Disamping itu penelitan ini juga menguji pengaruh masing - masing variabel kontekstual dengan SAM, pegnaruh SAM terhadap kinerja manajerial baik secara langsung, maupun dengan dimoderasi kedua variabel kontekstual. Responden dalam penelitian ini adalah manajer fungsional dari perusahaan percetakan skala besar di Banten. sampel yang digunakan berjumlah 100 manajerial fungsional. Alat analisis dengan menggunakan Structural Equational Modelling (SEM) melalui Partial Least Square (PLS) dan Sobel Test.Dalam penelitian ini, desentralisasi memiliki pengaruh positif signifikan terhdap kinerja manajerial, ketidakpastian tugas memiliki pengaruh positif signifikan terhadap kinerja manajerial, sistem akuntansi manajemen memiliki pengaruh positif signifikan terhadap kinerja manajerial. Hasil uji pengaruh tak langsung terbukti ketidak pastian tugas berpengaruh terhadap kinerja manajerial yang dimediasi oleh Sistem Akuntansi Manajemen.
\end{abstract}

Kata Kunci : Ketidakpastian tugas, desentralisasi, sistem akuntansi manajemen, Kinerja manajerial

\begin{abstract}
This study aims to test empirically the effect of two contextual variables, namely task uncertainty and decentralization on managerial performance with the Management Accounting System (SAM) as an intervening variable. Besides, this research also examines the effect of each contextual variable with SAM, the effect of SAM on managerial performance either directly or moderated by the two contextual variables.Respondents in this study were functional managers of large-scale printing companies in Banten. The sample used was 100 managerial functional. The analysis tool uses Structural Equational Modeling (SEM) through Partial Least Square (PLS) and Sobel Test. The results show that task uncertainty has a positive and significant effect on managerial performance, decentralization has a positive and significant impact on managerial performance, management accounting systems have a positive and significant impact on managerial performance, task uncertainty has a positive and significant impact on the management accounting system. , decentralization has a positive and significant effect on the management accounting system. The results of the
\end{abstract}


indirect effect test proved that task uncertainty had an effect on managerial performance mediated by the management accounting system.

Key word : Task uncertainty, decentralization, management accounting systems, managerial performance

\section{PENDAHULUAN}

Dalam sebuah perusahaan atau organisasi bisnis permasalahan tentang kinerja menjadi sebuah hal yang tak dapat dihindari. Kinerja merupakan salah satu faktor yang penting untuk dapat membuat organisasi atau persuahaan tersebut bisa tumbuh dan berkembang, sehingga hampir semua organisasi menggunakan kinerja sebagai salah satu indikator mengukur kemampuan sebuah perusahaan dalam mengelola sumber daya yang dimiliki untuk mencapai tujuan secara efektif dan efisien. Sistem Akuntansi Manajemen (SAM) merupakan sebuah serangkaian pengawasan dengan melakukan tindakan terhadap penilaian kinerja dan laporan pada sebuah organisasi (Chia, 1995)

Menurut laman berita wartaekonomi.co.id yang diakses pada bulan Juni 2020, pertumbuhan produksi industri manufaktur hanya tumbuh sebesar 4,01\%. Sedangkan industri percetakan mengalami kenaikan pertumbuhan produksi sebesar $19.58 \%$.

Untuk industri yang mengalami penurunan produksi adalah industri logam, turun sebesar $18,5 \%$, kemudian industri karet dan plastik turun sebesar $14 \%$, industry barang elektronik, computer dan optic turun $11 \%$ (Wartaekonomi, 2019). Industri percetakan mampu bertahan di tengah kondisi industri manufaktur lainya sedang lesu, Perubahan ekonomi secara global menuntut setiap perusahaan untuk meningkatkan efektifitas dalam operasi perusahaannya.

Dalam sebuah data yang di realese oleh Oxford Economics tahun 2013, industri percetakan di Indonesia mengalami pertumbuhan, dimana pada tahun 2012 pertumbuhannya diperkirakan 4,7\% dan nilai ini lebih tinggi bila dibandingakan dengan rata rata pertumbuhan industri percetakan di dunia yang hanya 1,6 \%. Adapun pemilihan Industri Percetakan di Provinsi Banten adalah banten merupakan salah satu Provinsi yang tingkat pertumbuhan industri percetakan yang cukup tinggi. Pada triwulan ketiga, realisasi investasi yang tercatat pada izin usaha baik penanaman modal dalam negeri (PMDN) atau penanaman modal asing (PMA) ada 15 proyek dengan nilai investasi Rp1,1 triliun. Dari 15 proyek tersebut, tersebar ke dalam 10 sektor, di antaranya sektor logam dasar, barang logam, mesin, elektronik, dan industri kertas dan percetakan. Industri kertas dan percetakan diprediksi dapat menyerap 260 tenaga kerja. (Radar Banten, 2015). Kemajuan industri percetakan di Banten tidak lepas dari sistem informasi akuntansi yang diterapakan dengan baik. Selain itu strategi yang digunakan haruslah strategi yang memiliki daya saing yang tinggi yang mana strategi ini mampu mewujudkan visi dan misi perusahaan baik jangka panjang maupun jangka pendek.

Semakin tinggi tingkat persaingan pasar, semakin modern teknologi produksi yang digunakan menyebabkan pengambil keputusan merasakan bahwa penggunaan sistem informasi akuntansi manajemen sangat penting. keefektifan desain informasi mempunyai hubungan yang signifikan dengan persepsi manajer terhadap ketidakpastian tugas, interpendensi organisasi, dan desentralisasi. semakin tinggi ketidakpastian tugas, semakin tinggi interpendensi, dan semakin terdesentralisasi organisasi, maka desain SAM akan semakin canggih.

Sistem Akuntansi Manajamen berperan dalam menyediakan informasi yang dibutuhkan pihak manajamen dalam melaksanakan pengawasan dan penilaian terhadap organisasi. Dimensi sistem akuntansi manajemen (SAM) terdiri dari empat karakteristik informasi yaitu : broad scope, aggregation, integration, timeliness Hirs (2001) Menyimpulkan bahwa 
ketidakpastian tugas mempengaruhi perilaku dan kinerja manajer. Dengan kata lain ketidakpastian tugas yang rendah menjadikan informasi akuntansi sebagai ukuran yang relatif sempurna ( complete) dalam menilai prestasi seseorang dan berdampak positif. Argumen yang dikemukakan bahwa semakin tidak pasti tugas seorang manajer, maka semakin sulit menyusun target yang memuaskan untuk dijadikan dasar penilaian prestasi manajer. Juga ditegaskan bahwa dalam situasi yang terdapat sediit ketidakpastian tugas, informasi akuntansi merupakan ukuran relatif sempurna dalam menangkap hasil tugas seseorang dan kecil kemungkinan terjadi perilaku negatif bawahan

Penelitian ini adalah replikasi dari penelitian sebelumnya yaitu dari Soobaroyen dan Poorundersing (2008). Perbedaan penelitian ini dengan penelitian sebelumnya adalah sampel yang digunakan adalah Percetakan Skala Besar di Banten sedangkan penelitian sebelumnya menggunakan sampel manufaktur tekstil, dalam penelitian sebelumnya menggunakan analisis jalur (path analysis) sedangkan penelitian ini menggunakan alat analisis Structural Equational Modelling (SEM) melalui Partial Least Square (PLS) dan Sobel Test.

\section{TINJAUAN PUSTAKA DAN PENGEMBANGAN HIPOTESIS}

\section{Teori Kontigensi}

Teori kontigensi dalam akuntansi manajemen sangat menarik untuk dijadikan dasar oleh para peneliti, karena pendekatan ini didasarkan pada asumsi bahwa dalam system akuntansi manajemen tidak ada yang secara umum selalu tepat dapat digunakan pada seluruh organisasi namun tergantung pada situasi dan kondisi yang ada dalam organisasi. (Otley, 1980). Para peneliti banyak menggunakan teori kontigensi untuk menganalisis dan mengontrol terutama di bidang akuntansi manajemen. Peneliti melakukan pengujian untuk melihat variable seperti ketidakpastian tugas, strategi, dan system informasi manajemen (Atiek Sri Purwati \& Zulaikha, 2006)

Teori kontingensi menyatakan semua variable dari suatu organisasi atau perusahaan harus terdapat kecocokan dan kesesuaian antara satu dengan yang lain. Melalui pendekatan kontijensi ini ada kemungkinan pengendalian intern, sistem akuntansi manajemen dan kapasitas sumber daya manusia pada masing-masing organisasi menyebabkan perbedaan kebutuhan karakteristik terhadap kinerja manajerial. Menurut (Otley 1980 dalam Andika Rante 2014) organisasi menghadapi kondisional (kontijensi) agar terbentuk konfigurasi yang sesuai sehingga diharapkan menghasilkan efektifitas organisasi dan kinerja manajerial meningkat.

\section{Pengaruh Desentralisasi terhadap Kinerja Manajerial}

Desentralisasi merupakan pendelagasian wewenang dari manajemen pusat ke manajemen yang lebih rendah. Pendelagasian ini membuat beban kerja manajemen pusat berkurang dan manajer pusat akan lebih focus pada pekerjaannya (Dwinarian et al., 2017) Desentralisasi diperlukan karena semakin kompleksnya pekerjaan, administratif, tugas dan tanggung jawab di sebuah organisasi. Maka dengan dilakukannya pendelegasian wewenang tersebut dapat meringankan beban kerja manajemen yang lebih tinggi. Selain itu menurut arina (2009) struktur organisasi yang melakukan kegiatan desentralisasi dapat mendorong para pemberi pelayanan kesehatan untuk memberikan pelayanan yang berkualitas

Penelitian yang dilakukan (Lempes, Ilat, \& Sabijono, 2014) tentang Desentralisasi Dan Sistem Akuntansi, menunjukkan bahwa Desentralisasi tidak berpengaruh terhadap kinerja manajer pada PT Sinar Galesong Prima dimanado dikarenakan manajer tingkat atas masih memegang peranan penting dalam setiap kegiatan perusahaan. Sebaliknya penelitian yang dilakukan oleh Bhakti (2011) mengatakan bahwa ada pengaruh yang signifikan antara 
desentralisasi terhadap kinerja manajerial, yang berarti semakin meningkat desentralisasi akan diikuti dengan kenaikan kinerja manajerial. Independensi yang dimiliki oleh manajer tersebut juga akan berdampak kepada manajer tersebut dapat dengan leluasa dalam berfikir dan bertindak untuk mencapai tujuan organisasi.

\section{H1 : Desentralisasi berpengaruh positif signifikan terhadap Kinerja Manajerial.}

\section{Pengaruh Ketidakpastian Tugas terhadap Kinerja Manajerial}

Menurut (Anom et al., 2018) ketidakpastian tugas merupakan perubahan yang cepat dan tidak terduga pada suatu keadaan atau kondisi. menurut Hirs ( 1981) ketidakpasitan tugas sangat dipengaruhi oleh kepercayaan individu tentang pemahaman cause - effect. Ketidakpastian tugas (task Uncertainty). Ketidakpastian Tugas dibagi menjadi tiga : 1.ketidakpastian tugas yang tinggi, 2. ketidakpastian tugas yang sedang dan 3.ketidakpastian tugas yang rendah. ketidakpstian tugas yang tinggi dapat diartikan sebagai suatu kondisi tugas yang tidak dapat dipahami dengan baik oleh karyawan. Dari ketidakpahaan atas tugas tersebut maka karyawan tidak memiliki pengetahuan yang cukup mengenai apa yang harus dilakukan. Ketidakpastian tugas yang rendah merupakan suatu kondisi dimana karyawan memahami dengan baik terhadap tugasnya

Hal ini akan menolong tenaga kerja untuk memahami tantangan dan risiko bisnis sehingga membuat mereka lebih bertanggungjawab, kreatif dan inovatif. Sehingga organiasi dapat bekerja dengan mudah dan efisien

Hirs (2001) berpendapat bahwa bahwa ketidakpastian tugas mempengaruhi perilaku dan kinerja manajer. Dengan kata lain ketidakpastian tugas yang rendah menjadikan informasi akuntansi sebagai ukuran yang relatif sempurna ( complete ) dalam menilai prestasi seseorang dan berdampak positif. Argumen yang dikemukakan bahwa semakin tidak pasti tugas seorang manajer, maka semakin sulit menyusun target yang memuaskan untuk dijadikan dasar penilaian prestasi manajer. Juga ditegaskan bahwa dalam situasi yang terdapat sediit ketidakpastian tugas, informasi akuntansi merupakan ukuran relatif sempurna dalam menangkap hasil tugas seseorang dan kecil kemungkinan terjadi perilaku negatif bawahan

H2 : Ketidakpastian Tugas berpengaruh positif dan signifikan terhadap Kinerja Manajerial

\section{Pengaruh Sistem Akuntansi Manajemen Terhadap Kinerja Manajerial}

Sistem akuntansi manajemen (SAM) bertugas dalam menyediakan informasi yang dibutuhkan organisasi untuk memudahkan pengawasan dan tindakan terhadap penilaian. Karakteristik sistem akuntansi manajemen menghasilkan informasi yang sangat berguna untuk membantu para manajer organisasi dalam pengambilan keputusan yang pada akhirnya dapat untuk lebih meningkatkan kinerja manajerialnya. Mia dan Chanel dalam Mulyaningtyas (2008:26) berpendapat bahwa, seorang manager dapat melakukan pekerjaan nya dengan baik bila mereka dapat menggunakan informasi yang disediakan oleh Sistem Akuntansi Manajemen. Sejalan dengan penelitian yang dilakukan oleh (Syam \& Maryasih, 2016) tentang Sistem Akuntansi Manajemen, menunjukkan kesimpulan bahwa Sistem 
Akuntansi Manajemen berhubungan positif dan signifikan dengan Kinerja Organisasi yang dimediasi oleh Ketidakpastian Lingkungan dan Desentralisasi.

H3 : Sistem Akuntansi Manajemen berpengaruh positif dan signifikan Terhadap Kinerja Manajerial

\section{Pengaruh Ketidakpastian Tugas terhadap Sistem Akuntansi Manajemen}

Ketidakpastian tugas merupakan gap antara informasi yang dibutuhkan dengan jumlah informasi yang dimiliki untuk melakukan sebuah tugas. Oleh karena itu manajer membutuhkan informasi yang di hasilkan Sistem Akuntansi Manajemen dalam pengambilan keputusan saat menghadapi kondisi ketidakpastian tugas yang cukup tinggi ( Chong, 1996). Dalam menghadapi ketidakpastian tugas yang tinggi, manajer menjadi kesulitan dalam mengidentifikasi tugas yang menjadi prioritas untuk di kerjakan, sehingga membutuhkan informasi yang di hasilkan SAM dalam melakukan pekerjaan manajer. sehingga Ketidakpastian tugas berpengaruh terhadap sistem akuntansi manajemen yang meliputi dimensi: skope, ketepatan waktu, agregasi untuk mempermudah pekerjaan manager dalam pengambilan keputusan

H4 : Ketidakpastian Tugas Berpengaruh positif dan signifikan terhadap Sistem Akuntansi Manajemen meliputi dimensi: skope, ketepatan waktu, agregasi dan integrasi sebagai variabel intervening.

\section{Pengaruh Desentralisasi terhadap Sistem Akuntansi Manajemen}

Penelitian yang dilakukan Chenhall dan Morris (1986) menemukan bahwa desentralisasi berpengaruh positif terhadap dua dimensi SAM, yaitu aggregation dan integration, sedangkan desentralisasi tidak berpengaruh terhadap dua dimensi SAM lainnya, yaitu broad scope dan timeliness, penelitian ini membuktikan informasi yang terintegrasi dapat menurunkan masalah koordinasi pada sub unit organisasi. dukungan lain ditemukanpada penelitian soobaroyen dan poorundersing ( 2008 ) yang menemukan bahwa tingkat desentralisasi berhubungan positif denga keempat dimensi SAM

\section{H5 :Desentralisasi berpengaruh positif signifikan terhadap Sistem Akuntansi} Manajemen yang meliputi dimensi: skope, ketepatan waktu, agregasi dan integrasi sebagai variabel intervening.

\section{METODE PENELITIAN}

Objek yang di teliti adalah ketidakpastian tugas, desentralisasi dan kinerja manajerial serta sistem akuntansi manajemen pada industri percetakan skala besar di Banten. Metode penelitian menyangkut prosedur dan cara melakukan pengolahan data yang diperlukan untuk menjawab atau memecahkan masalah penelitian termasuk menguji hipotesis. Penelitian ini ditempuh melalui penelitian survey dimana informasi yang dikumpulkan dengan menggunakan kuesioner 
Populasi dari penelitian ini adalah seluruh manajer dan supervisor pada industri percetakan di Provinsi Banten. Sampel dalam penelitian ini adalah para manajer dan supervisor tingkat menengah pada industri percetakan bersekala besar di Provinsi Banten.

Tabel 1

Operasional Variabel

\begin{tabular}{|c|c|c|c|c|}
\hline Variabel & Definisi & Indikator & Skala & $\begin{array}{c}\text { Sumber } \\
\text { data }\end{array}$ \\
\hline $\begin{array}{c}\text { Desentralisasi } \\
\text { (X1) }\end{array}$ & $\begin{array}{l}\text { Desentralisasi } \\
\text { merupakan } \\
\text { pendelegasian } \\
\text { wewenang dan } \\
\text { tanggung jawab } \\
\text { kepada para manajer. } \\
\text { Tingkat pendelegasian } \\
\text { itu sendiri } \\
\text { menunjukkan sampai } \\
\text { sejauh mana } \\
\text { manajemen yang lebih } \\
\text { tinggi mengizinkan } \\
\text { manajemen } \\
\text { dibawahnya untuk } \\
\text { membuat kebijakan } \\
\text { secara independen }\end{array}$ & $\begin{array}{l}\text { 1.Kondisi administrative } \\
\text { 2.Program dan kegiatan } \\
\text { 3.Penentuan pegawai } \\
\text { 4.Prioritas kegiatan } \\
\text { 5.Penambahan dan } \\
\text { pemutasian pegawai }\end{array}$ & Ordinal & 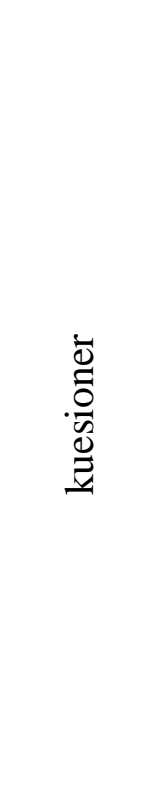 \\
\hline $\begin{array}{l}\text { Ketidakpasti } \\
\text { an Tugas (X2) }\end{array}$ & $\begin{array}{l}\text { Ketidakpastian oleh } \\
\text { Miliken dalam } \\
\text { Susilawati dan Anwar } \\
\text { (2004) memberikan } \\
\text { pengertian secara } \\
\text { definisional sebagai } \\
\text { rasa } \\
\text { ketidakmampuan } \\
\text { dalam } \\
\text { memprediksi sesuatu } \\
\text { secara tepat. }\end{array}$ & $\begin{array}{l}\text { 1. Pembimbing Pekerjaan } \\
\text { 2. Pekerjaan Rutinitas } \\
\text { 3. Pekerjaan paling } \\
\text { Utama } \\
\text { 4. Langkah Pekerjaan }\end{array}$ & Ordinal & \\
\hline & $\begin{array}{l}\text { metode formal yang } \\
\text { menyediakan } \\
\text { informasi yang akurat } \\
\text { dan tepat waktu } \\
\text { kepada manajemen } \\
\text { untuk mempermudah } \\
\text { proses pengambilan } \\
\text { keputusan dan } \\
\text { membuat organisasi } \\
\text { dapat melakukan }\end{array}$ & $\begin{array}{l}\quad \text { Broad of scope } \\
\text { 1.Informasi Eksternal } \\
\text { 2.Informasi non finansial } \\
\text { 3.Informasi yang } \\
\text { Berorientasi kedepan } \\
\qquad \\
\quad \text { Timelines } \\
\text { 1.Frekuensi pelaporan } \\
\text { 2.Kecepatan pelaporan } \\
\text { 3.Laporan disediakan }\end{array}$ & & \\
\hline
\end{tabular}




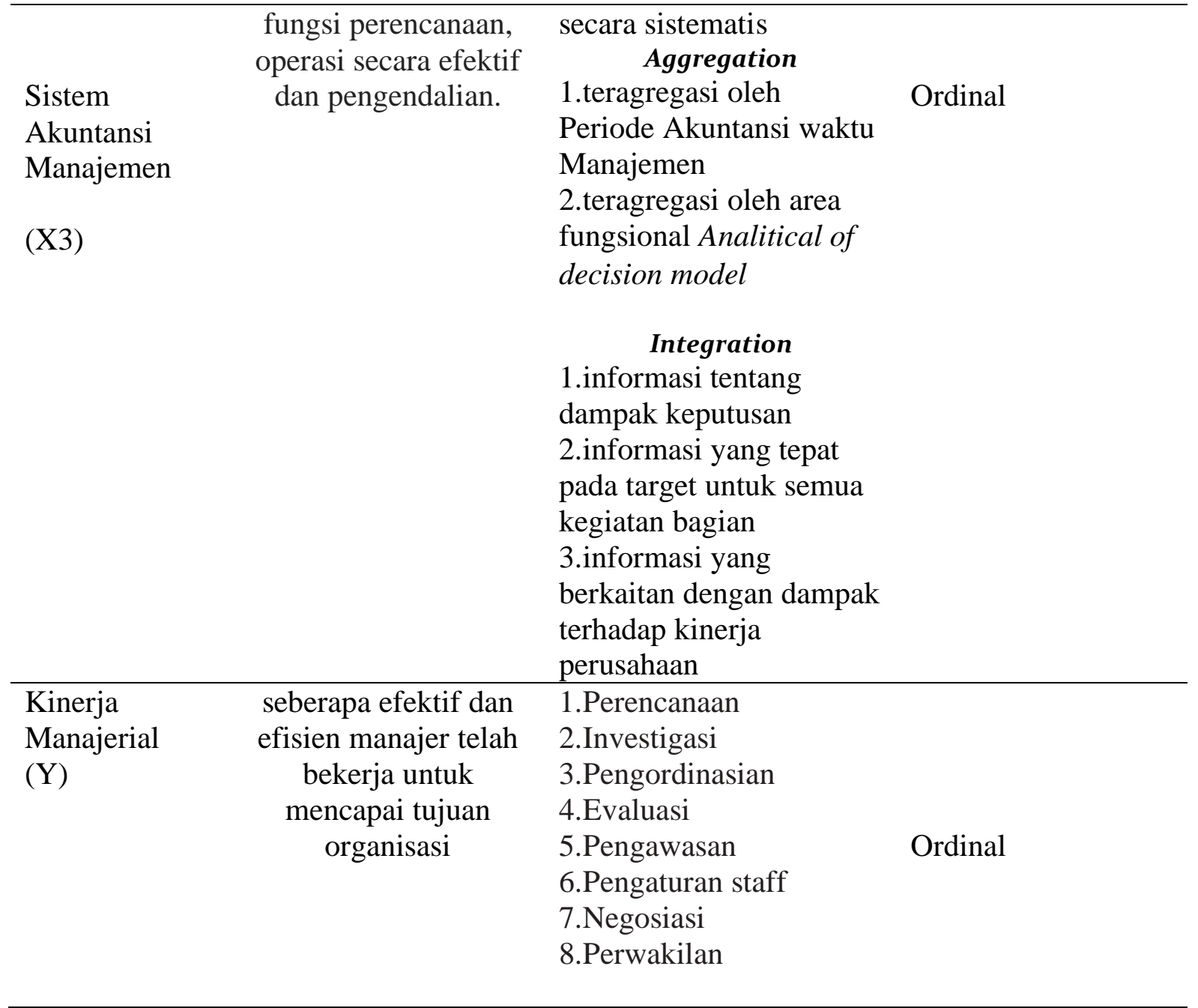

Responden yang menjadi sampel penelitian ini adalah para manajer middle dan lower yang berjumlah 100 manajer yang ada industri percetakan. Teknik penarikan sampel pada penelitian ini adalah penarikan sampel purposive. Sampling purposive adalah teknik penarikan sampel dengan pertimbangan tertentu. (Sugiyono, $2004: 61$ ) Kriteria sampel yang diajukan sebagai berikut: (1) terlibat dan mempunyai pengaruh dalam proses penyusunan anggaran, (2) mengetahui kinerja dalam aktivitas manajemen dan terdapat pelimpahan wewenang dari atasan ke bawahan. Penentuan kriteria tersebut dengan pertimbangan bahwa manajer sebagai sampel penelitian, diharapkan dapat merespon penelitian ini. Dimana tujuan penelitian ini adalah untuk membuktikan hipotesis bahwa terdapat pengaruh ketidakpastian tugas dan desentralisasi terhadap kinerja manajerial dengan sistem akuntansi manajemen sebagai variabel intervening. Penyebaran kuesioner sebanyak 100 kuesioner. Dari jumlah tersebut kuesioner yang kembali dan dapat diolah berjumlah 42 kuesioner atau hanya $42 \%$. Kuesioner yang tidak kembali berjumlah 58 kuesioner atau $58 \%$. Kuesioner yang tidak kembali kemungkinan dikarenakan kuesioner yang diajukan tidak sampai di tangan responden. Hal tersebut dapat terjadi karena beberapa hal seperti kesibukan atau padatnya pekerjaan para responden atau kuesioner yang tidak disampaikan. Kalkulasi antara jumlah kuesioner yang disebarkan dengan yang berhasil dikumpulkan terdapat pada tabel 1

\section{Tabel 2}

Persentase Pengiriman dan Pengambilan Kuesioner 


\begin{tabular}{ccc}
\hline Kuesioner & Jumlah & Persentase \\
\hline Kuesioner yang disebar & 100 & $100 \%$ \\
Kuesioner kembali & 42 & $42 \%$ \\
Kuesioner yang tidak kembali & 58 & $58 \%$ \\
Kuesioner yang dapat diolah & 42 & $100 \%$ \\
\hline
\end{tabular}

Uji kualitas data pada penelitian ini dilakukan meliputi uji reliabilitas dan uji validitas dengan software Partial Least Square (PLS). Dalam penelitian ini pengujian hipotesis menggunakan pendekatan Partial Least Square (PLS) dengan menggunakan software SmartPLS. PLS adalah model persamaan struktural (SEM) yang berbasis komponen atau (variance).

\section{HASIL DAN PEMBAHASAN}

\section{Pengujian Kualitas Data}

\section{Uji Validitas}

Uji validitas digunakan untuk mengukur sah atau valid tidaknya suatu kuesioner. Suatu kuesioner dikatakan valid jika pertanyaan pada kuesioner tersebut mampu untuk mengungkapkan sesuatu yang akan diukur oleh kuesioner tersebut. Pengujian validitas data dalam penelitian ini adalah dengan menggunakan software Smart PLS dengan Outer Model, yaitu Convergent validity yang dilihat dengan nilai square root of average variance extracted (AVE) masing-masing konstruk dimana nilainya harus lebih besar dari 0,5 (Chin dalam Ghozali, 2006

Tabel 3

Average Variance Extracted (AVE)

\begin{tabular}{|c|c|c|c|}
\hline Konstrak & AVE & $\sqrt{A V E}$ & Keterangan \\
\hline Agregasi & 0.878 & & Valid \\
\hline Desentralisasi & 0.831 & & Valid \\
\hline Integrasi & 0.770 & & Valid \\
\hline Ketidak Pastian Tugas & 0.754 & & Valid \\
\hline Kinerja Manajerial & 0.713 & & Valid \\
\hline SAM & 0.747 & & Valid \\
\hline Scope & 0.874 & & Valid \\
\hline Timeliness & 0.805 & & Valid \\
\hline
\end{tabular}

Sumber: Data primer diolah dengan SmartPLS (2020)

Tabel 4

Correlations of Latent Variables

\begin{tabular}{|c|c|c|c|c|c|c|c|c|}
\hline & Agregasi & $\begin{array}{c}\text { Desen } \\
\text { tralisasi }\end{array}$ & Integrasi & $\begin{array}{c}\text { Ketidak } \\
\text { Pastian } \\
\text { Tugas }\end{array}$ & $\begin{array}{c}\text { Kinerja } \\
\text { Mana } \\
\text { jerial }\end{array}$ & SAM & Scope & $\underset{\text { ness }}{\text { Timeli }}$ \\
\hline Agregasi & 1.000 & & & & & & & \\
\hline Desentralisasi & 0.693 & 1.000 & & & & & & \\
\hline Integrasi & 0.853 & 0.757 & 1.000 & & & & & \\
\hline Ketidak & 0.803 & 0.692 & 0.695 & 1.000 & & & & \\
\hline
\end{tabular}




\section{Pastian Tugas}

\begin{tabular}{lllllllll} 
Kinerja & & & & & & & & \\
Manajerial & 0.871 & 0.830 & 0.848 & 0.839 & 1.000 & & & \\
SAM & 0.934 & 0.800 & 0.964 & 0.784 & 0.907 & 1.000 & & \\
Scope & 0.848 & 0.812 & 0.876 & 0.750 & 0.847 & 0.945 & 1.000 & \\
Timeliness & 0.881 & 0.803 & 0.905 & 0.770 & 0.901 & 0.971 & 0.924 & 1.000 \\
\hline
\end{tabular}

Sumber: Data primer diolah dengan SmartPLS (2016)

Tabel 4 menjelaskan nilai dari AVE dan akar AVE dari konstruk desentralisasi, sistem akuntansi manajemen dan kinerja manajemen. Dapat dilihat bahwa setiap konstruk (variabel) tersebut memiliki nilai AVE diatas 0,5. Hal ini menunjukkan bahwa setiap konstruk tersebut memiliki nilai validitas yang baik dari setiap indikatornya atau kuesioner yang digunakan untuk mengetahui hubungan desentralisasi, sistem akuntansi manajemen dan kinerja manajerial dapat dikatakan valid.

\section{Uji Reliabilitas}

Uji reliabilitas dimaksudkan untuk mengukur internal consistency suatu kuesioner yang merupakan indikator dari variabel atau konstruk. Suatu kuesioner dikatakan reliabel jika jawaban seseorang terhadap pernyataan menghasilkan jawaban yang sama dari waktu ke waktu. Pengujian reliabilitas data dalam penelitian ini menggunakan software SmartPLS dengan kriteria uji Composite reliability. Suatu data dikatakan reliabel jika Composite reliability lebih besar dari 0,7 (Ghozali, 2006).

Uji reliabilitas diperkuat dengan nilai alpha cronbach's. Batasan uji reliabilitas cronbach's alpha $>0.7$. Nilai cronbach's alpha yang didapat konstrak desentralisasi 0.949, ketidakpastian tugas 0.891, kinerja manajerial 0.949 dan system akuntansi manajemen 0.981. Hasil nilai Cronbach's alpha selengkapnya disajikan pada tabel di bawah ini.

\section{Tabel 5}

Nilai Cronbach's Alpha

\begin{tabular}{ccl}
\hline Konstrak & $\begin{array}{c}\text { Cronbachs } \\
\text { Alpha }\end{array}$ & \\
\hline Agregasi & 0.953 & Reliable \\
Desentralisasi & 0.949 & Reliable \\
Integrasi & 0.950 & Reliable \\
Ketidak Pastian Tugas & 0.891 & Reliable \\
Kinerja Manajerial & 0.949 & Reliable \\
SAM & 0.981 & Reliable \\
Scope & 0.926 & Reliable \\
Timeliness & 0.939 & Reliable \\
\hline
\end{tabular}

\section{Analisis Data}

\section{Menilai Outer Model (Measurement Model)}

Outer model merupakan model yang menspesifikasi hubungan antara variable laten dengan indikator-indikatornya atau bisa dikatakan bahwa outer model mendefinisikan bagaimana setiap indikator berhubungan dengan variable latennya. Outer model untuk nilai konvergen (konvergent validity), nilai diskriminan (discriminant validity), composite 
reliability, Average Variance Extracted (AVE) dan alpha cronbach's. Model PLS Algorithm disajikan Model PLS Algorithm disajikan pada gambar di bawah ini.

\section{Gambar 1 . Model PLS Algorithm}

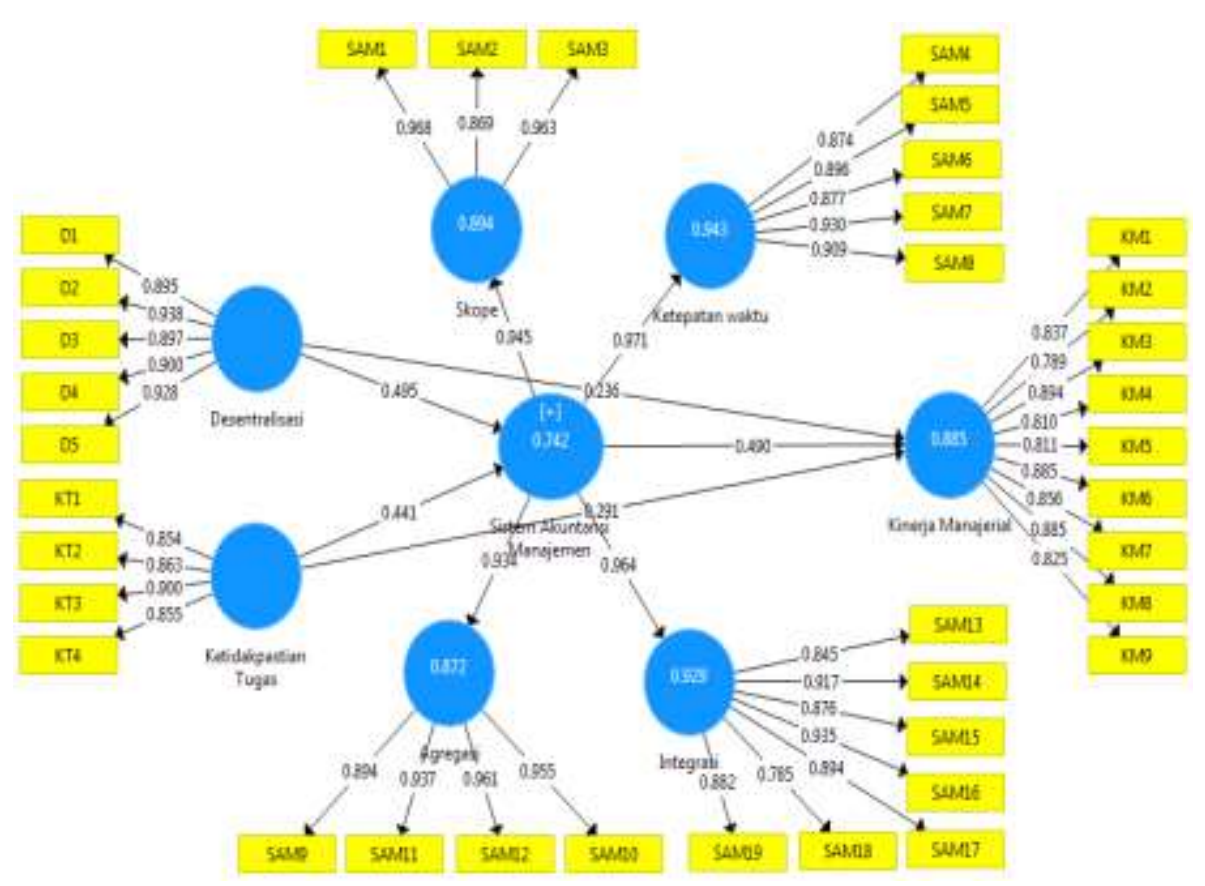

Keterangan

$\mathrm{D}$

: Desentralisasi

SAM : Sistem Akuntansi Manajemen

KM : Kinerja Manajerial

KT : Ketidakpastian Tugas

Pada Model measurement dilakukan untuk menguji hubungan (nilai loading) antara indikator dengan konstruk (variabel laten). Untuk Convergent validity dari model pengukuran dengan refleksif indikator dinilai berdasarkan korelasi antara item score/component score yang diestimasi dengan software SmartPLS. Ukuran refleksif individual dikatakan tinggi jika berkorelasi lebih dari 0,7 dengan konstruk (variabel laten) yang diukur. Namun menurut Chin (dalam Ghozali 2006), untuk penelitian tahap awal dari pengembangan, skala pengukuran nilai loading 0,5 sampai 0,6 dianggap cukup memadai.

\section{1) Konvergen validitas}

Nilai konvergen yaitu mengukur besarnya Loading Factor untuk masing-masing variabel laten. Loading factor diatas 0,70 sangat direkomendasikan, namun demikian Loading Factor diatas 0.60 masih dapat ditolerir sepanjang model masih dalam tahap pengembangan. Konstrak ketidakpastian tugas yang diukur dengan 4 indikator, nilai loading tertinggi pada indikator KT3 sebesar 0.900 dan terendah pada indikator KT1 
sebesar 0.853. Konstrak kinerja manajerial yang memiliki 9 indikator, nilai loading tertinggi diperoleh pada indikator KM3 sebesar 0.894 dan terendah indikator KM2 sebesar 0.789. Konstrak Sistem Akuntansi manajemen yang diukur dengan 19 indikator, nilai loading tertinggi pada indikator SAM7 sebesar 0.930 dan terendah pada indikator SAM18 sebesar 0.693. Dari semua indikator tersebut diatas memiliki nilai loading > 0.6, hal ini membuktikan bahwa semua indikator valid sebagai pengukur konstraknya.

2) Diskriminan validitas.

Nilai diskriminan berguna untuk menilai apakah variabel memiliki discriminan validity yang memadai yaitu dengan cara membandingkan korelasi indikator dengan konstrak yang dituju harus lebih besar dibandingkan korelasi dengan konstrak yang lain. Jika korelasi indikator tersebut memiliki nilai lebih tinggi dibandingkan dengan korelasi indikator dengan konstrak lain, maka dikatakan variabel tersebut memiliki discriminant validity yang tinggi. Nilai ini dapat dilihat pada nilai cross loading factor. Hasil nilai cross loading selengkapnya sebagai berikut :

\section{Tabel 6}

Nilai Cross Loading

\begin{tabular}{|c|c|c|c|c|c|}
\hline & $\begin{array}{c}\text { Desen } \\
\text { tralisasi }\end{array}$ & $\begin{array}{c}\text { Ketepatan } \\
\text { waktu }\end{array}$ & $\begin{array}{c}\text { Ketidakpastian } \\
\text { Tugas }\end{array}$ & $\begin{array}{c}\text { Kinerja } \\
\text { Manajerial }\end{array}$ & $\begin{array}{c}\text { Sistem Akuntansi } \\
\text { Manajemen }\end{array}$ \\
\hline D1 & 0.895 & 0.714 & 0.583 & 0.747 & 0.718 \\
\hline D2 & 0.938 & 0.766 & 0.668 & 0.756 & 0.770 \\
\hline D3 & 0.897 & 0.692 & 0.605 & 0.721 & 0.683 \\
\hline D4 & 0.900 & 0.750 & 0.678 & 0.793 & 0.738 \\
\hline D5 & 0.928 & 0.734 & 0.617 & 0.765 & 0.735 \\
\hline KM1 & 0.728 & 0.733 & 0.747 & 0.837 & 0.747 \\
\hline KM2 & 0.746 & 0.723 & 0.676 & 0.789 & 0.683 \\
\hline KM3 & 0.751 & 0.743 & 0.786 & 0.894 & 0.773 \\
\hline KM4 & 0.647 & 0.686 & 0.645 & 0.810 & 0.670 \\
\hline KM5 & 0.695 & 0.761 & 0.642 & 0.811 & 0.814 \\
\hline KM6 & 0.716 & 0.831 & 0.624 & 0.885 & 0.822 \\
\hline KM7 & 0.666 & 0.754 & 0.806 & 0.856 & 0.781 \\
\hline KM8 & 0.726 & 0.837 & 0.682 & 0.885 & 0.830 \\
\hline KM9 & 0.628 & 0.769 & 0.756 & 0.825 & 0.760 \\
\hline KT1 & 0.634 & 0.598 & 0.854 & 0.721 & 0.620 \\
\hline KT2 & 0.530 & 0.698 & 0.863 & 0.735 & 0.708 \\
\hline KT3 & 0.634 & 0.700 & 0.900 & 0.742 & 0.709 \\
\hline KT4 & 0.609 & 0.675 & 0.855 & 0.716 & 0.681 \\
\hline SAM1 & 0.755 & 0.877 & 0.694 & 0.793 & 0.892 \\
\hline SAM2 & 0.781 & 0.860 & 0.734 & 0.813 & 0.887 \\
\hline SAM3 & 0.737 & 0.851 & 0.671 & 0.764 & 0.869 \\
\hline SAM4 & 0.723 & 0.874 & 0.742 & 0.814 & 0.827 \\
\hline SAM5 & 0.666 & 0.896 & 0.631 & 0.739 & 0.877 \\
\hline SAM6 & 0.689 & 0.877 & 0.606 & 0.786 & 0.833 \\
\hline & & & & & \\
\hline
\end{tabular}




\begin{tabular}{|l|l|l|l|l|l|} 
SAM7 & 0.791 & 0.930 & 0.774 & 0.875 & 0.930 \\
\hline SAM7 & 0.791 & 0.930 & 0.774 & 0.875 & 0.930 \\
\hline SAM8 & 0.730 & 0.909 & 0.699 & 0.826 & 0.885 \\
\hline SAM9 & 0.654 & 0.858 & 0.721 & 0.758 & 0.864 \\
\hline SAM10 & 0.710 & 0.843 & 0.805 & 0.860 & 0.901 \\
\hline SAM11 & 0.637 & 0.801 & 0.737 & 0.834 & 0.850 \\
\hline SAM12 & 0.595 & 0.799 & 0.746 & 0.811 & 0.883 \\
\hline SAM13 & 0.723 & 0.811 & 0.688 & 0.763 & 0.858 \\
\hline SAM14 & 0.765 & 0.862 & 0.699 & 0.811 & 0.910 \\
\hline SAM15 & 0.551 & 0.757 & 0.548 & 0.723 & 0.838 \\
\hline SAM16 & 0.753 & 0.849 & 0.660 & 0.809 & 0.898 \\
\hline SAM17 & 0.586 & 0.819 & 0.579 & 0.739 & 0.862 \\
\hline SAM18 & 0.570 & 0.606 & 0.480 & 0.612 & 0.693 \\
\hline SAM19 & 0.683 & 0.827 & 0.590 & 0.733 & 0.837 \\
\hline
\end{tabular}

Pada tabel diatas dapat dilihat bahwa nilai loading indikator D1 terhadap konstrak desentralisasi sebesar 0.895 lebih tinggi dibanding konstrak lain yaitu ke ketidakpastian tugas 0.583 , kinerja manajemen 0.747 dan sistem akuntansi manjemen 0.718. Demikian juga untuk D2, D3 dan D4 memiliki loading lebih tinggi pada konstrak yang dituju dibandingkan ke konstrak lainnya.

Pada indikator KM1 nilai loading terhadap kinerja manjerial 0.837 lebih tinggi dibandingkan ke konstrak lain yaitu desentralisasi 0.728 , ketidakpastian tugas 0.747 , dan system akuntansi manajemen 0.747. Demikian juga untuk indikator KM2 -KM9 memiliki nilai loading yang lebih tinggi ke blok yang dituju dibanding ke blok yang lain. Pada indikator KT1 nilai loading terhadap ketidakpastian tugas 0.854 lebih tinggi dibandingkan ke konstrak lain yaitu desentralisasi 0.634 , kinerja manajerial 0.721 dan system akuntansi manajemen 0.620. Demikian juga untuk indikator KT2, KT3 dan KT4 memiliki nilai loading yang lebih tinggi ke blok yang dituju dibanding ke blok lain yang lain.

Pada indikator SAM1 nilai loading terhadap system akuntansi manajemen 0.892 lebih tinggi dibandingkan ke konstrak lain yaitu desentralisasi 0.755 , ketidakpastian tugas 0.694, dan kinerja manajerial 0.793. Demikian juga untuk indikator SAM2 - SAM19 memiliki nilai loading yang lebih tinggi ke blok yang dituju dibanding ke blok yang lain

\section{3) Composite Reliability}

Nilai composite reliability yang tinggi menunjukkan adanya konsistensi yang baik dari setiap indikator dalam variabel laten untuk mengukur variabel tersebut. Kriteria nilai composite reliability $>0.7$ menunjukkan bahwa variabel tersebut memiliki internal konsistensi yang baik. Nilai composite realibility selengkapnya disajikan pada tabel di bawah ini.

Tabel 7

Nilai Composite Reliability 


\begin{tabular}{cc}
\hline Desentralisasi & 0.961 \\
Ketidakpastian Tugas & 0.925 \\
Kinerja Manajerial & 0.957 \\
Sistem Akuntansi Manajemen & 0.982 \\
\hline
\end{tabular}

Pada tabel di atas menunjukkan bahwa nilai composite reliability desentralisasi sebesar 0.961, ketidakpastian tugas 0.925 , kinerja manajerial 0.957 dan system akuntansi manajemen sebesar 0.982. Semua konstrak tersebut memiliki nilai composite reliability $>0.70$ maka dikatakan memiliki internal konsistensi yang baik.

\section{4) Average Variance Extracted (AVE)}

Nilai AVE menunjukkan nilai varians pada masing-masing indikator dalam konstrak yang dapat ditangkap oleh variabel tersebut lebih banyak dibandingkan dengan varians yang diakibatkan oleh kesalahan pengukuran. Nilai AVE yang diharapkan $>0.5$. Nilai AVE konstrak desentralisasi 0.831 , ketidakpastian tugas 0.754 , kinerja manajerial 0.713 dan system akuntansi manajemen sebesar 0.747 Hasil selengkapnya disajikan pada tabel di bawah ini.

\section{Tabel 8}

Nilai Average Variance Extracted (AVE)

\begin{tabular}{cc}
\hline Konstrak & AVE \\
\hline Desentralisasi & 0.831 \\
Ketidakpastian Tugas & 0.754 \\
Kinerja Manajerial & 0.713 \\
Sistem Akuntansi Manajemen & 0.747 \\
\hline
\end{tabular}

5) Cronbach's Alpha

Uji reliabilitas diperkuat dengan nilai alpha cronbach's. Batasan uji reliabilitas cronbach's alpha > 0.7. Nilai cronbach's alpha yang didapat konstrak desentralisasi 0.949, ketidakpastian tugas 0.891, kinerja manajerial 0.949 dan system akuntansi manajemen 0.981. Hasil nilai Cronbach's alpha selengkapnya disajikan pada tabel di bawah ini.

Tabel 9

Nilai Cronbach's Alpha

\begin{tabular}{cc}
\hline Konstrak & Composite Reliability \\
\hline Desentralisasi & 0.949 \\
Ketidakpastian Tugas & 0.891 \\
Kinerja Manajerial & 0.949 \\
Sistem Akuntansi Manajemen & 0.981 \\
\hline
\end{tabular}

\section{Uji Model Structural (Inner Model)}

Untuk menguji model structural dilakukan dengan melihat nilai $\mathrm{R}^{2}$ yang merupakan uji Goodness of the fit. Konstrak system akuntansi manejemen memperoleh nilai $\mathrm{R}^{2}$ sebesar 
0.745 yang dapat diinterpretasikan bahwa varian pada system akuntansi manejemen dapat dijelaskan oleh konstrak desentralisasi,

ketidakpastian tugas sebesar $74.2 \%(0.742 \times 100 \%)$ sedangkan sisanya $25.8 \%(100 \%$ $74.2 \%$ ) dijelaskan oleh variabel lain diluar yang diteliti. Begitu juga dengan konstrak kinerja manajerial dengan nilai $\mathrm{R}^{2}$ yang didapat sebesar 0.885 atau $88.5 \%$. Nilai ini menunjukkan bahwa varian konstrak kinerja manajerial dapat dijelaskan oleh konstrak desentralisasi, ketidakpastian tugas dan sistem akuntansi manajerial sebesar $88.5 \%$ sedangkan sisanya $11.5 \%$ $(100 \%-88.5 \%)$ dijelaskan oleh variabel lain yang tidak diteliti. Hasil nilai $\mathrm{R}^{2}$ selengkapnya disajikan pada tabel di bawah ini.

Tabel 10

Nilai R-Square

\begin{tabular}{cc}
\hline Konstrak & R Square \\
\hline Kinerja Manajerial & 0.885 \\
Sistem Akuntansi Manajemen & 0.742 \\
\hline
\end{tabular}

Uji selanjutnya adalah melihat signifikansi pengaruh antar konstrak independen terhadap dependen dan menjawab apa yang telah dihipotesiskan. Pengujian dengan taraf signifikansi $5 \%$ jika nilai t-statistic > 1.96 maka hipotesis nol $(\mathrm{H} 0)$ ditolak. Nilai t-statistik koefisien pengaruh dari konstrak laten diperoleh dari PLS Bootstrapping. Hasil Model PLS Bootstrapping disajikan pada gambar di bawah ini.

Gambar 2.

Model PLS Bootstraping

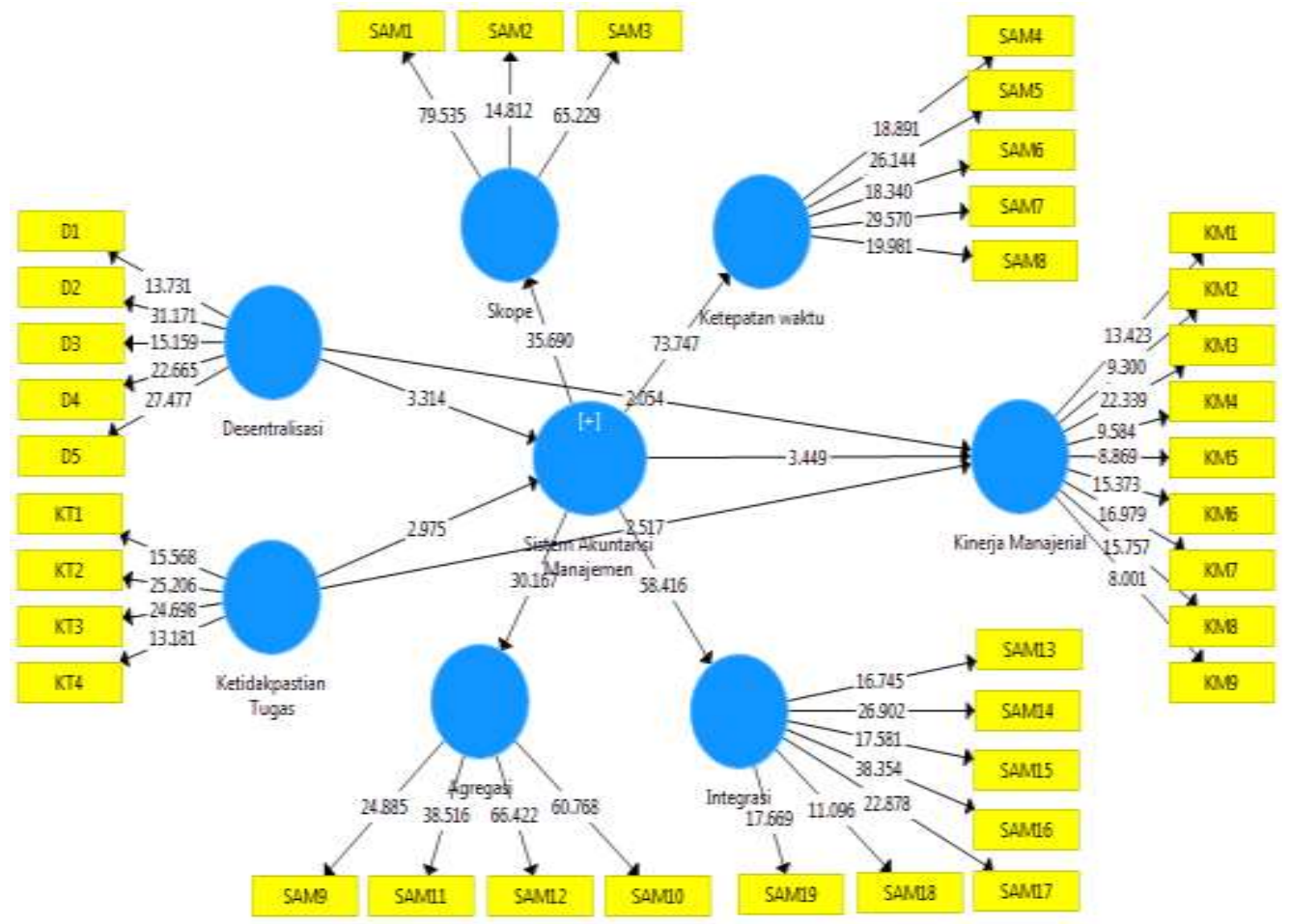

Nilai koefisien parameter dapat dilihat pada nilai (original sample) dan nilai signifikansi t-statistik dapat dilihat pada tabel di bawah ini. 
Tabel 11

Nilai Koefisien (Original Sample), Standard Error dan T-Statistics dan p-values

\begin{tabular}{ccccc}
\hline Pengaruh & $\begin{array}{c}\text { Original Sample } \\
(\mathbf{O})\end{array}$ & $\begin{array}{c}\text { Standard Error } \\
\text { (STERR) }\end{array}$ & $\begin{array}{c}\text { T Statistics } \\
(\text { (O/STERR) }\end{array}$ & P Values \\
\hline $\begin{array}{c}\text { Desentralisasi -> } \\
\text { Kinerja Manajerial }\end{array}$ & 0.236 & 0.115 & 2.054 & 0.040 \\
$\begin{array}{c}\text { Desentralisasi -> } \\
\text { Sistem Akuntansi Manajemen } \\
\text { Ketidakpastian Tugas -> } \\
\quad \text { Kinerja Manajerial }\end{array}$ & 0.495 & 0.149 & 3.314 & 0.001 \\
$\begin{array}{c}\text { Ketidakpastian Tugas -> } \\
\text { Sistem Akuntansi Manajemen }\end{array}$ & 0.291 & 0.116 & 2.517 & 0.012 \\
Sistem Akuntansi Manajemen -> & 0.441 & 0.148 & 2.975 & 0.003 \\
$\quad$ Kinerja Manajerial & 0.490 & 0.142 & 3.449 & 0.001 \\
\hline
\end{tabular}

Pengujian hipotesis sebagai berikut :

1. Nilai koefisien pengaruh ketidakpastian tugas terhadap kinerja manajerial sebesar 0.291 , standard error 0.116, t-statistik 2.517dan p-value 0.012. Karena nilai t-statistik $2.517>$ 1.96 dan p-value $0.012<0.05$ maka tolak hipotesis nol (H0). Hal ini berarti membuktikan bahwa terdapat pengaruh yang signifikan positif ketidakpastian tugas terhadap kinerja manajerial.

2. Nilai koefisien pengaruh desentralisasi terhadap kinerja manajerial sebesar 0.236 , standard error 0.115, t-statistik 2.054 dan p-value 0.040. Karena nilai t-statistik $2.054>$ 1.96 dan p-value $0.040<0.05$ maka tolak hipotesis nol (H0). Hal ini terbukti bahwa terdapat pengaruh positif signifikan desentralisasi terhadap kinerja manajerial.

3. Nilai koefisien pengaruh system akuntansi manajemen terhadap kinerja manjerial sebesar 0.490 , standard error 0.142 , t-statistik 3.449 dan p-value 0.001 . Karena nilai t-statistik $3.449>1.96$ dan p-value $0.001<0.05$ maka tolak hipotesis nol (H0). Hal ini membuktikan terdapat pengaruh yang signifikan positif sistem akuntansi manajemen terhadap kinerja manajerial.

4. Nilai koefisien pengaruh ketidakpastian tugas terhadap system akuntansi manajemen sebesar 0.441 , standar error 0.148 , t-statistik 2.975 dan p-value 0.003 . Karena nilai tstatistik $2.975>1.96$ dan p-value $0.003<0.05$ maka tolak hipotesis nol (H0). Hal ini membuktikan bahwa terdapat pengaruh psoitif signifikan ketidakpastian tugas terhadap sistem akuntansi manajemen.

5. Nilai koefisien pengaruh desentralisasi terhadap system akuntansi manajemen sebesar 0.495 , standar error 0.149 , t-statistik 3.314 dan p-value 0.001 . Karena nilai t-statistik $3.314>1.96$ dan p-value $0.001<0.05$ maka tolak hipotesis nol (H0). Hal ini membuktikan bahwa desentralisasi berpengaruh positif signifikan terhadap Sistem Akuntansi Manajemen yang meliputi dimensi: skope, ketepatan waktu, agregasi dan integrasi.

Untuk menguji apakah koefisien pengaruh tidak langsung dari desentralisasi dan ketidakpastian tugas terhadap kinerja manajerial melalui system akuntansi manajerial sebagai mediasi dengan melakukan uji sobel test. Salah satu cara adalah uji z dari sobel atau disebut sobel test. Perhitungan nilai z dari sobel tes sebagai berikut : 
Perhitungan sobel test untuk mendapatkan nilai z sebagai berikut :

1. Koefisien pengaruh tidak langsung dari desentralisasi ke kinerja manajerial melalui system akuntansi manajemen sebesar $0.495 \times 0.490=0.243$. Perhitungan nilai z sobel tes sebagai berikut :

$$
\begin{aligned}
& z=\frac{a b}{\sqrt{\left(b^{2} S E_{a}^{2}\right)+\left(a^{2} S E_{b}^{2}\right)}} \\
& z=\frac{0.495 \times 0.490}{\sqrt{\left(0.490^{2} 0.149^{2}\right)+\left(0.495^{2} 0.142^{2}\right)}} \\
& z=\frac{0.243}{\sqrt{0.1015}} \\
& z=2.389
\end{aligned}
$$

\section{Dimana :}

$\mathrm{a}=$ koefisien pengaruh desentralisasi ke system akuntansi manajemen.

$\mathrm{b}=$ koefisien pengaruh system akuntansi manajemen ke kinerja manajerial.

$\mathrm{SE}_{\mathrm{a}}=$ standard error pengaruh desentralisasi ke system akuntansi manajemen.

$\mathrm{SE}_{\mathrm{b}}=$ standard error pengaruh system akuntansi manajemen ke kinerja manajerial.

Oleh karena z sebesar 2.389 lebih besar dari Z 1.98 pada tingkat signifikansi 0.05 maka dapat disimpulkan bahwa koefisien tidak langsung desentralisasi ke kinerja manajerial melalui system akuntansi manajemen sebesar 0.243 adalah signifikan. Hal ini menunjukkan bahwa system akuntansi manajemen signifikan memediasi pengaruh desentralisasi terhadap kinerja manajerial.

2. Koefisien pengaruh tidak langsung dari ketidakpastian tugas ke kinerja manajerial melalui system akuntansi manajemen sebesar 0.441 x $0.490=0.216$. Perhitungan nilai $\mathrm{z}$ sobel tes sebagai berikut :

$$
\begin{aligned}
& z=\frac{a b}{\sqrt{\left(b^{2} S E_{a}^{2}\right)+\left(a^{2} S E_{b}^{2}\right)}} \\
& z=\frac{0.441 \times 0.490}{\sqrt{\left(0.490^{2} 0.148^{2}\right)+\left(0.441^{2} 0.142^{2}\right)}} \\
& z=\frac{0.216}{\sqrt{0.095}} \\
& z=2.252
\end{aligned}
$$

\section{Dimana :}

$\mathrm{a}=$ koefisien pengaruh ketidakpastian tugas ke sistem akuntansi manajemen.

$\mathrm{b}=$ koefisien pengaruh system akuntansi manajemen ke kinerja manajerial.

$\mathrm{SE}_{\mathrm{a}}=$ standard error pengaruh ketidakpastian tugas ke sistem akuntansi manajemen. 
$\mathrm{SE}_{\mathrm{b}}=$ standard error pengaruh system akuntansi manajemen ke kinerja manajerial.

Oleh karena z sebesar 2.252 lebih besar dari Z 1.98 pada tingkat signifikansi 0.05 maka dapat disimpulkan bahwa koefisien koefisien tidak langsung ketidakpastian tugas ke kinerja manajerial melalui system akuntansi manajemen sebesar 0.216 adalah signifikan. Hal ini menunjukkan bahwa system akuntansi manajemen signifikan memediasi pengaruh ketidakpastian tugas terhadap kinerja manajerial.

\section{SIMPULAN}

Penelitian ini bertujuan untuk menguji pengaruh variable Desentralisasi dan ketidakpastian tugas terhadap kinerja manajerial melalui sistem akuntansi manajemen (SAM) Disamping itu penelitan ini juga menguji pengaruh masing - masing variabel kontekstual dengan SAM, pegnaruh SAM terhadap kinerja manajerial baik secara langsung, maupun dengan dimoderasi kedua variabel kontekstual. Penelitian ini dilakukan terhadap industry percetakan skala besar. Berdasarkan hasil analisis data pembahasan yang telah di tuangkan, maka dapat diambil kesimpulan bahwa

1. Terdapat pengaruh positif signifikan desentralisasi terhadap kinerja manajerial. Hal ini dibuktikan dengan Nilai koefisien pengaruh desentralisasi terhadap kinerja manajerial sebesar 0.236, standard error 0.115, t-statistik 2.054 dan p-value 0.040. Desentralisasi mampu meningkatkan kinerja manajerial, hal ini sejalan denga penelitian yang dilakukan oleh Soobaroyen dan Poorundersing (2008) yang menyatakan bahwa desentralisasi berpengaruh positif kinerja

2. Terdapat pengaruh yang signifikan positif ketidakpastian tugas terhadap kinerja manajerial. Hal ini dibuktikan dengan t-statistik 2.517dan p-value 0.012. Karena nilai t-statistik $2.517>1.96$ dan p-value $0.012<0.05$. dalam hal ini Ketidakpastian Tugas mampu meningkatkan Kinerja Manajerial. Hal ini sesuai dengan teori yang dikemukakan oleh Hirst (1981) dalam Anwar (2004), bahwa semakin tidak pasti situasi tugas manager, maka makin sulit untuk menyusun target yang memuaskan dan kemudian dijadikan dasar pengevaluasian prestasi manajer dalam organisasi. Hasil penelitian ini mendukung beberapa pendapat dan teori tentang yang dikemukakan Ketidakpastian Tugas oleh para ahli sebagai berikut: Hirst (1981) dalam Anwar (2004),

3. Terdapat pengaruh yang signifikan positif sistem akuntansi manajemen terhadap kinerja manajerial. Nilai koefisien pengaruh system akuntansi manajemen terhadap kinerja manjerial sebesar 0.490 , standard error 0.142 , t-statistik 3.449 dan p-value 0.001 membuktikan bahwa ada pengaruh positif signifikan antara Sistem akuntansi manajemne terhadap kinerja manajerial. SAM mampu meningkatkan kinerja manajerial, karena dengan informasi yang didapatkan dari Sistem Akuntansi Manajemen membantu para manajer organisasi dalam pengambilan keputusan yang pada akhirnya dapat untuk lebih meningkatkan kinerja manajerialnya. Hal ini sejalan dengan penelitian Soobaroyen dan Poorundersing (2008)

4. terdapat pengaruh positif signifikan ketidakpastian tugas terhadap sistem akuntansi manajemen. Dalam menghadapi ketidakpastian tugas yang tinggi, manajer menjadi kesulitan dalam mengidentifikasi tugas yang menjadi prioritas untuk di kerjakan, sehingga membutuhkan informasi yang di hasilkan SAM dalam melakukan pekerjaan manajer. Dalam penelitian ini, Ketidakpastian Tugas mampu mendukung peningkatan 
Sistem Akuntansi Manajemen. Hasil penelitian ini mendukung beberapa pendapat dan teori tentang yang dikemukakan Ketidakpastian Tugas oleh para ahli salah satunya adalah Hirst (1981) dalam Anwar (2004),

5. Desentralisasi berpengaruh positif signifikan terhadap Sistem Akuntansi Manajemen yang meliputi dimensi: skope, ketepatan waktu, agregasi dan integrasi. Nilai koefisien pengaruh desentralisasi terhadap system akuntansi manajemen sebesar 0.495 , standar error 0.149, t-statistik 3.314 dan p-value 0.001. Karena nilai t-statistik $3.314>1.96$ dan p-value $0.001<0.05$ hal inimembuktikan bahwa Desentralisasi berpengaruh positif terhadap Sistem Akuntansi Manajemen.

\section{KETERBATASAN DAN SARAN}

Dari analisis dan kesimpulan yang telah diuraikan, maka peneliti memberikan beberapa saran sebagai berikut:

1. Diharapkan untuk penelitian selanjutnya dapat menambahkan variable eksternal lainnya seperti (ketidakpastian tugas, ketidakpastian lingkungan ) dimana variable tersebut dapat mempengaruhi kinerja manajerial.

2. Peneliti selanjutnya diharapkan dapat mengembangkan penelitian dari berbagai entitas bisnis lainnya seperti sektor perbankan, perhotelan, jasa, dagang maupun BUMN.

\section{DAFTAR PUSTAKA}

Anom, Sulaeman, M., Kusnandar, H. F., Sulaeman, M., \& Kusnandar, H. F. (2018). Pengaruh informasi akuntansi dan ketidakpastian tugas terhadap kinerja manajerial ( studi pada PDAM Tirta Anom Banjar ) Abstrak. November 2017. https://doi.org/10.26486/jramb.v3i2.413

Atiek Sri Purwati, \& Zulaikha, S. (2006). Teori Kontinjensi, Sistem Pengendalian Manajemen Dan Outcomes Perusahaan: Implikasinya Dalam Riset Masa Kini Dan Masa Yang Akan Datang. I, 4(1), 1-11.

Ahmasafari, Chitranigrum 1995. "Analisis Pengaruh Interaksi Antara Sistem Akuntansi Allison, P.D. 1977. “Testing for Interraction in Multiple Regression”. American Journal of Sociology.pp. $144-153$.

Atkitson. 1995. Management Accounting. Englewood Cliffs, New Jersey: Prentice Hall

Chong, V.K. 1996. "Management Accounting Systems, Task Uncertainty and Managerial Performance: A Research Note". Accounting, Organizations and Society. Vol. 21, No. 25. pp. $415-421$.

Desmiyawati, "Desentralisasi, Ketidakpastian Lingkungan Dan Sistem Akuntansi Manajemen Terhadap Kinerja Manajerial , 2010, Pekbis Jurnal, Fakultas Ekonomi Universitas Riau.

Dwinarian, F., Asnawi, M., \& Sanggenafa, M. (2017). Pengaruh Desentralisasi Dan Sistem Akuntansi Manajemen Terhadap Kinerja Manajerial (Studi Kasus Di Perbankan Kota Jayapura dan Kabupaten Jayapura). Jurnal Akuntansi \& Keuangan Daerah, 12(1), 3955. 
Ernawan, V. Budi. 1995. "Analisa Pengaruh Interaksi Ketidakpastian Lingkungan, Desentralisasi, dan Informasi Akuntansi Manajemen terhadap Prestasi Kerja Manajer". Skripsi Universitas Gadjah Mada, Yogyakarta. Tidak dipublikasikan.

Gerloff, E.A. 1985. Organizational Theory and Design - A Strategic Approach for Management, New York: Mc. Graw-Hill.

Gordon, E.A. and Miller. 1986. “A Contigency Framework for the Design of Accounting Information Systems". Accounting, Organizations and Society. pp. 59-69.

Gordon, L.A. and V.K. Narayanan. 1984. "Management Accounting Systems, Perceived Environmental Uncertainty and Organization Structure: An Empirical Investigation". Accounting, Organizations and Society. Vol.9, No.1. pp. $259-285$.

Govindarajan, V. 1986. "Impact of Participation in the Budgetary Process on Management Attitudes and Performance : Universalistic and Contigency Perspectives". Decision Sciences. pp. $496-516$.

Gul and Chia, Y.M. 1994. "The Effect of Management Accounting Systems, Perceived Environmental Uncertainty and Decentralization on Managerial Performance: A Tes of Three-way Interaction”. Accounting, Organizations and Society. Vol. 19. pp 413 426.

Heller, F.A and Yulk. 1989. "Participation in Managerial Decision Making and Situational Variable". Organizational Behavior and Human Performance. pp. 230.

Hellriegel, D. and J.W. Slocum. 1987. Management: Contingency Approach. Addison Wesley. Inc.Chenhall, R.H. dan D. Morries. 1986. "The Impact of Structure, Environment, and Interdependence on the Perceived Usufulness of Management Accounting Systems". Accounting Review. pp. 16-35.

Indriantoro dan Supomo. B. 1998. "Pengaruh Struktur dan Kultur Organisasional Terhadap Keefektipan Anggaran Partisipasi dalam Peningkatan Kinerja Manajerial”. Kelola, No.18/VII/1998. pp. 61-80.

Jaryanto, 2008, "Pengaruh Desentralisasi terhadap kinerja Manajerial dengan sistem Akuntansi Manajamen ( Broadscope, Timeliness, Agregation dan Integration) Sebagai Variabel Intervening" Fokus Ekonomi, Universitas Sebelas Maret Surakarta, Surakarta.

Mahoney, T.A., T.H. Jerdee, and S.J. Carrol. Development of Managerial Performance: A Research Approach. Cincinnati, OH: South-Western.

Mutmainah, Kurniawati, 2009, Pengaruh Ketidakpastian Tugas Dan Desentralisasi Terhadap Kinerja Manajerial Dengan Sistem Akuntansi Manajemen Sebagai Variabel Intervening, Tesis, Universitas Diponegoro, Semarang

Miah, N.Z. and Mia L. 1996. "Decentralization, Accounting Control and Performance of Government Organizations: A New Zealand Empirical Study". Financial Accountibility and Management.August 1996. pp. 173 - 189.

Nunnanly, J.C.1978. Psychometric Theory. New York: Mc. Graw - Hill. Otley, D.T. 1980. "The Contingency Theory of Management Accounting: Acheivement and Prognosis". Accounting, Organizations and Society. p. 422. 
Riyanto, Bambang. 1997. "Strategic Uncertainty, Management Accounting Systems and Performance: Emperical Investigation of Contigency Theory at a Firm Level". Unpublished Ph. D, Dissertation, Temple University Schoonhoven, C.B. "Problems with Contigency Theory: Testing Assumptions Hidden Within the Language of Contingency Theory". Administrative Science Quarterly. Vol. 26, No. 3. pp. 349 377.

Soobaroyen dan Poorundersing, 2008, The effectiveness of management accounting systems Evidence from functional managers in a developing country, Managerial Auditing Journal Vol. 23 No. 2, pp. 187-219

Thompson, J.D. 1986. Organizations in Action. Mc.Graw-Hill. Waterhouse, J.H. and Tiessen. 1995. A Contingency Framework for Management Accounting Systems Research, Accounting, dalam Managerial Accounting - The Behavioural Foundation. J.L. Livingstone, Colombus, Ohio: Grid Inc. pp. 65 - 80.

Widiastuti, Kiki, 2011, Pengaruh Teknologi Informasi dan Saling Ketergantungan terhadap Kinerja Manajerial dengan Karakteristik Sistem Akuntansi Manajemen sebagai Variabel Intervening, Karya Ilmiah, Universitas Diponegoro Semarang.

Wiryana, Augustinepengaruh Karakteristik Informasi Sistem Akuntansi Manajemen Terhadap Kinerja Manajerial Dengan Variabel Moderasi Strategi Bisnis, Perceived Environmental Uncertainty (Peu), Ketidakpastian Tugas Dan Desentralisasi, E-Journal Magister Akuntasi Trisakti Volume. 1 Nomor. 2 September 2014 Hal. 155-180, Jakarta. 